INTERNATIONAL JOURNAL OF RESEARCHES IN BIOSCIENCES, AGRICULTURE AND TECHNOLOGY (C) VISHWASHANTI MULTIPURPOSE SOCIETY (Global Peace Multipurpose Society) R. No. MH-659/13(N) www.ijrbat.in

\title{
PHYTOSOCIOLOGICAL STUDIES ON WANZALOLI SACRED GROVE OF DAPOLI TAHSIL, DISTRICT RATNAGIRI (M.S.), INDIA.
}

\author{
R. L. Ghalme \\ P.G. and Research Laboratory, Department of Botany, \\ Dapoli Urban Bank Senior Science College Dapoli, Dist. Ratnagiri-415712.
} Email- rlghalme@gmail.com

\begin{abstract}
:
Sacred groves are the forests or places preserved on religious grounds near the village or away from the village. Wanzaloli sacred grove having area 8.17 hectors and is 42 K.M. to West-North side from Dapoli city. To study the distribution, dominance, ecological success of species in community and structure of community, phytosociological studies were carried out in 2012-2013. It was observed that, the vegetation in sacred grove is moist semi-evergreen type. Total 54 species belongs to 47 genera of total 29 families are reported. Mammea suriga (Butch.Ham.Ex Roxb.) Kosterm, Mangifera indica L. Ixora brachiata Roxb., Holigarna arnottiana Hook., Combretum latifolium B1., Zanthoxylum rhetsa Dc. and Xantolis tomentosa (Roxb.) Raf. are well distributed in the study area. Based on basal area and IVI values the plants like Antiaris toxicaria (Pers.) Leschen., Bombax ceiba L., Combretum latifolium Bl., Ficus parasitica Koen. ex. Willd., Garcinia xanthochymus Hook., Ixora brachiata Roxb., Mammea suriga (Butch. Ham.Ex Roxb.) Kosterm., Mangifera indica L., Terminalia bellerica Roxb., Terminalia chebula Retz., Xantolis tomentosa (Roxb.) Raf. Gmelina arborea Roxb. and Ficus calosa Willd are dominant and ecologically more successful species in study area.
\end{abstract}

Keywords: Sacred grove, Phytosociological, distribution, dominant, semi-evergreen, community, etc.

\section{Introduction}

Forest pockets preserved on religious grounds are known as sacred graves / Dev - rai (Vartak et al. 1986). Well preserved sacred groves support the climax type of vegetation rich in species of trees, herbs, shrubs and climbers, such groves contains different birds and wild animals. The sacred groves play an important role in preservation of plant species which are very rare or extinct elsewhere. The sacred groves show optimum growth of the vegetation relevant to local terrain and climate. Apart from lofty and magnificent trees many rare and endangered species are also associated with sacred groves (Vartak et al., 1987).

Vartak and Gadgil (1981) studied the Janni Grove of Mangoan of Poona district in respect to study the flora, ecological aspects and ethno-botany. After exploration of sacred groves in Southern-Western Ghats in Kerala, Unikrishnan (1990) noted the various ecological roles of sacred groves in that area. Kulkarni and Nipunage (2009) evaluated floristic diversity and ecological aspect of Dhup-Rahat form Pune district. They reported that the name Dhup-Rahat is given due to magnificent trees of Dhup (Canarium strictum Roxb.) very rare plant in Maharashtra. They also reported 29 species with their mean frequency.

Topography \& Climatic factors of study areas - Dapoli:

Topography and climatic factors determines the type of vegetations. Hence, the study of ethnographic study is necessary which includes the physical and climatic conditions of region. It includes the various factors like topography, location, climate, rainfall, soil, irrigation etc.

The topography Dapoli tahsil is totally hilly area. It lies between $17^{\circ} 4-54^{\prime \prime}$ North latitude and $73^{\circ} 10-39^{\prime \prime}$ East longitude and $250 \mathrm{mts}$. altitude. The predominant soil in the tahsil is lateritic, which vary in colour from bright red to brownish red. The soil is acidic, rich with iron and organic matter. The water holding capacity of soil is poor, and immediately dries after the rainfall. Being a costal tahsil, the variation in the temperature during the day time throughout the year is not large. The average maximum temperature not goes beyond $32^{\circ} \mathrm{C}$ and minimum temperature $20^{\circ} \mathrm{C}$. The average humidity ranges from 69 to $95 \%$ (Anonymous 1962). The entire annual rainfall occurs during the month of June to October. Usually, in July month the heaviest rainfall is received. The average rainfall received was about $3800 \mathrm{~mm}$ /annum (Anonymous, 2008 to 2012).

Wanzaloli is a small village with total population of about 600 and is $42 \mathrm{Km}$ away to West-North side of Dapoli. The ownership of the Wanzaloli sacred grove is in the hands of Revenue department. It covers total 8.15 hectors area with Jakmata, Kaleshwari and Shankar Deities and well preserved moist semi-evergreen forest. The quantitative study of vegetation is called Phytosociology. To study the distribution, dominance, ecological success of species in community and structure 
of community, the present topic entitled, "Phytosociological studies on Wanzaloli Sacred grove of Dapoli Tahsil, District Ratnagiri (M.S.), India." was undertaken in 2012-2013.

\section{Materials and Methods}

Frequent field visits were organized to Wanzaloli sacred grove to study the phytosociological aspects. 10 Quadrates of $10 \mathrm{M} \mathrm{x}$ $10 \mathrm{M}$ were laid down randomly at different height in sacred grove. The number of plants of each species was listed and the diameter at breast height $(\mathrm{DBH})$ of the species above 50.00 $\mathrm{cm}$ was recorded. The Phyto-sociological parameters like relative frequency, relative density, abundance, basal area and importance value index (IVI) for each species were calculated. Dispersion of plant species in a community (Frequency), numerical strength of the species (density) and dominance was studied by the following methods of Misra (1968) and Pandeya et al. (1968). The phytosociological data recorded during observation was analyzed. In order to study the ecological success and dominance plant species in community with single value, Important Value Index are calculated and shown in following Table no.01. The frequency classes are analyzed and shown in table no. 2 .

The plant specimens in flowering or fruiting condition were collected. The collected plant species were identified using flora of the Presidency of Bombay (Cooke, 1958); Flora of Maharashtra State Monocotyledons (Sharma et al., 1996); Flora of Maharashtra State Dicotyledons Vol-I (Singh et al. 2000); Flora of Maharashtra State Dicotyledons Vol-II (Singh et al. 2001) and Flora of Sawantwadi (Kulkarni, 1988).The collected plant specimens were preserved (Jain and Rao, 1977).

The plants are deposited as voucher specimens in the Herbarium of the Department of Botany, Dapoli Urban Bank Senior Science College Dapoli, Dist. Ratnagiri (M.S.). The plants which falls under RET categories, their photographs were maintained due to rarity.

\section{Result and Discussion:}

Basal area refers to the ground actually penetrated by the stem. It is one of the chief characteristics to determine dominance. It is clear that species like Antiaris toxicaria (Pers.) Leschen, Ficus parasitica Koen. ex. Willd.,Terminalia bellerica Roxb., Bombax ceiba L. Holigarna arnottiana Hook. Terminalia chebula Retz.,Gmelina arborea Roxb., Ficus calosa Willd. are dominant in the study area.

In order to study the ecological success and dominance plant species in community with single value, Important Value Index are calculated. The highest IVI value of 10 species are Antiaris toxicaria (Pers.) Leschen. (33.98), Mammea suriga (Butch. Ham.Ex Roxb.) Kosterm.(28), Mangifera indica L.(15.67), Terminalia bellerica Roxb. (14.01), Terminalia chebula Retz.( 14.01), Ixora brachiata Roxb.(10.37), Garcinia xanthochymus Hook.(8.5), Ficus parasitica Koen. ex. Willd. (8.49)., Zanthoxylum rhetsa Dc.(7.58) and Xantolis tomentosa (Roxb.) Raf. (7.52). This indicates that these 10 species are dominant and more ecologically successful species from Wanzaloli sacred grove.

Table No.1: General ecological parameters.

\begin{tabular}{|c|c|c|c|c|c|c|c|c|c|c|c|}
\hline $\begin{array}{l}\text { Sr. } \\
\text { No. }\end{array}$ & Botanical Name & IT. & OCC & FRE & ABD & DEN & BA & $\begin{array}{c}\text { R.De } \\
\text {. }\end{array}$ & R.F. & R.D & I.V.I. \\
\hline 1 & Acacia catechu (L.) Willd. & 04 & 02 & 20 & 02 & 0.4 & 0.06 & 1.80 & 1.45 & 0.26 & 3.51 \\
\hline 2 & $\begin{array}{l}\text { Antiaris toxicaria (Pers.) } \\
\text { Leschen. }\end{array}$ & 02 & 02 & 20 & 01 & 0.2 & 7.15 & 0.90 & 1.45 & $\begin{array}{c}31.6 \\
3\end{array}$ & $\begin{array}{c}33.9 \\
8\end{array}$ \\
\hline 3 & Aprosa lindleyana (Wight) Baill. & 02 & 02 & 20 & 01 & 0.2 & 0.13 & 0.90 & 1.45 & 0.57 & 2.92 \\
\hline 4 & Argyreia nervosa Bojer. & 01 & 01 & 10 & 01 & 0.1 & $\begin{array}{c}0.00 \\
1\end{array}$ & 0.45 & 0.72 & $\begin{array}{c}0.00 \\
4\end{array}$ & 1.17 \\
\hline 5 & Bauhinia racemosa Lam. & 01 & 01 & 10 & 01 & 0.1 & 0.07 & 0.45 & 0.72 & 0.30 & 1.47 \\
\hline 6 & Bombax ceiba L. & 04 & 02 & 20 & 02 & 0.1 & 0.91 & 1.80 & 1.45 & $\begin{array}{c}4.01 \\
2\end{array}$ & 7.26 \\
\hline 7 & $\begin{array}{l}\text { Calycopteris floribunda (Roxb.) } \\
\text { Poir. }\end{array}$ & 05 & 04 & 40 & 1.25 & 0.5 & 0.08 & 2.26 & 2.91 & 0.35 & 5.52 \\
\hline 8 & Careya arborea Roxb. & 03 & 03 & 30 & 01 & 0.3 & 0.45 & 1.35 & 2.18 & 1.99 & 5.52 \\
\hline 9 & $\begin{array}{l}\text { Carissa congestaWight } \\
\text { var.congesta }\end{array}$ & 06 & 03 & 30 & 02 & 0.6 & $\begin{array}{c}0.00 \\
2\end{array}$ & 2.71 & 2.18 & $\begin{array}{c}0.00 \\
8\end{array}$ & 4.89 \\
\hline 10 & Caryota urens Linn & 05 & 04 & 40 & 1.25 & 0.5 & 0.06 & 2.26 & 2.91 & 0.26 & 5.43 \\
\hline 11 & Combretum latifolium Bl. & 06 & 06 & 60 & 01 & 0.6 & 0.04 & 2.71 & 4.37 & 0.17 & 7.25 \\
\hline 12 & Derris scandens Benth. & 01 & 01 & 10 & 01 & 0.1 & 0.07 & 0.45 & 0.72 & 0.30 & 1.47 \\
\hline 13 & Dillenia pentagyna Roxb. & 03 & 03 & 30 & 01 & 0.3 & 0.30 & 1.35 & 2.18 & 1.32 & 4.85 \\
\hline 14 & $\begin{array}{l}\text { Diploclisia glaucescens (B1.) } \\
\text { Diels }\end{array}$ & 01 & 01 & 10 & 01 & 0.1 & $\begin{array}{c}0.00 \\
5\end{array}$ & 0.45 & 0.72 & 0.02 & 1.19 \\
\hline 15 & Entada rheedei spreng & 01 & 01 & 10 & 01 & 0.1 & 0.08 & 0.45 & 0.72 & 0.35 & 1.52 \\
\hline
\end{tabular}




\begin{tabular}{|c|c|c|c|c|c|c|c|c|c|c|c|}
\hline 16 & Ficus callosa Willd & 02 & 02 & 20 & 01 & 0.2 & 0.98 & 0.90 & 1.45 & 4.33 & 6.68 \\
\hline 17 & Ficus exasperataVahl & 01 & 01 & 10 & 01 & 0.1 & 0.01 & 0.45 & 0.72 & 0.04 & 1.21 \\
\hline 18 & Ficus parasitica Koen. ex. Willd. & 04 & 03 & 30 & 1.33 & 0.4 & 1.02 & 1.80 & 2.18 & 4.51 & 8.49 \\
\hline 19 & Ficus virens (lacor) Roxb. & 01 & 01 & 10 & 01 & 0.1 & 0.69 & 0.45 & 0.72 & 3.05 & 4.22 \\
\hline 20 & Firmiana colorata (Roxb.) R. Br. & 01 & 01 & 10 & 01 & 0.1 & 0.03 & 0.45 & 0.72 & 0.13 & 1.3 \\
\hline 21 & Garcinia indica Choiss & 05 & 03 & 30 & 1.66 & 0.5 & 0.12 & 2.26 & 2.18 & 0.53 & 4.97 \\
\hline 22 & Garcinia xanthochymus Hook & 12 & 04 & 40 & 03 & 1.2 & 0.04 & 5.42 & 2.91 & 0.17 & 8.5 \\
\hline 23 & Gmelina arborea Roxb. & 02 & 02 & 20 & 01 & 0.2 & 0.69 & 0.90 & 1.45 & 3.05 & 5.4 \\
\hline 24 & Gnetum ula Roxb. & 03 & 03 & 30 & 01 & 0.3 & 0.08 & 1.35 & 2.18 & 0.35 & 3.88 \\
\hline 25 & Helicteres isora L. & 01 & 01 & 10 & 01 & 0.1 & 0.01 & 0.45 & 0.72 & 0.04 & 1.21 \\
\hline 26 & Holarrhena pubescens wall & 01 & 01 & 10 & 01 & 0.1 & $\begin{array}{c}0.00 \\
03\end{array}$ & 0.45 & 0.72 & $\begin{array}{c}0.00 \\
1\end{array}$ & 1.17 \\
\hline 27 & Holigarna arnottiana Hook. & 06 & 05 & 50 & 1.2 & 0.6 & 0.03 & 2.71 & 3.64 & 0.13 & 6.48 \\
\hline 28 & $\begin{array}{l}\text { Holoptelea integrifolia } \\
\text { (Roxb.)Planch. }\end{array}$ & 02 & 02 & 20 & 01 & 0.2 & 0.75 & 0.90 & 1.45 & 3.31 & 5.66 \\
\hline 29 & Ixora brachiata Roxb. & 11 & 07 & 70 & 1.57 & 1.1 & 0.07 & 4.97 & 5.10 & 0.30 & $\begin{array}{c}10.3 \\
7\end{array}$ \\
\hline 30 & Leea macrophylla Roxb. & 03 & 01 & 10 & 03 & 0.3 & $\begin{array}{c}0.00 \\
03\end{array}$ & 1.35 & 0.72 & $\begin{array}{c}0.00 \\
1\end{array}$ & 2.07 \\
\hline 31 & $\begin{array}{l}\text { Macaranga peltata (Roxb.) } \\
\text { Muell. }\end{array}$ & 03 & 03 & 30 & 01 & 0.3 & 0.04 & 1.35 & 2.18 & 0.17 & 3.7 \\
\hline 32 & $\begin{array}{l}\text { Mammea suriga (Butch. Ham. } \\
\text { Ex Roxb.) Kosterm. }\end{array}$ & 45 & 10 & 100 & 4.5 & 4.5 & 0.08 & $\begin{array}{c}20.3 \\
6\end{array}$ & 7.29 & 0.35 & 28 \\
\hline 33 & Mangifera indica $\mathrm{L}$. & 14 & 09 & 90 & 1.55 & 1.4 & 0.63 & 6.33 & 6.56 & 2.78 & $\begin{array}{c}15.6 \\
7\end{array}$ \\
\hline 34 & $\begin{array}{l}\text { Memecylon umbellatum Burm. } \\
\text { Var. umbellatum }\end{array}$ & 09 & 04 & 40 & 2.25 & 0.9 & 0.05 & 4.07 & 2.91 & 0.22 & 7.2 \\
\hline 35 & Meyna laxiflora Robyns & 04 & 02 & 20 & 02 & 0.4 & 0.05 & 1.80 & 1.45 & 0.22 & 3.47 \\
\hline 36 & Mimusops elengi L. & 03 & 03 & 30 & 01 & 0.3 & 0.69 & 1.35 & 2.18 & 3.05 & 6.58 \\
\hline 37 & Mucuna monosperma DC. & 01 & 01 & 10 & 01 & 0.1 & $\begin{array}{l}0.00 \\
2\end{array}$ & 0.45 & 0.72 & $\begin{array}{l}0.00 \\
8\end{array}$ & 1.17 \\
\hline 38 & Plumeria rubra L. & 01 & 01 & 10 & 01 & 0.1 & 0.78 & 0.45 & 0.72 & 3.45 & 4.62 \\
\hline 39 & Saraca asoca Linn & 03 & 01 & 30 & 03 & 0.3 & 0.05 & 1.35 & 0.72 & 0.22 & 2.29 \\
\hline 40 & Smilax ovalifolia Roxb. & 05 & 02 & 20 & 2.5 & 0.5 & $\begin{array}{c}0.00 \\
03\end{array}$ & 2.26 & 1.45 & $\begin{array}{c}0.00 \\
1\end{array}$ & 3.71 \\
\hline 41 & Sterculia guttata Roxb. & 02 & 02 & 20 & 01 & 0.2 & 0.09 & 0.90 & 1.45 & 0.39 & 2.39 \\
\hline 42 & $\begin{array}{l}\text { Symphorema involucratum } \\
\text { Roxb. }\end{array}$ & 02 & 02 & 20 & 01 & 0.2 & 0.01 & 0.90 & 1.45 & 0.04 & 2.39 \\
\hline 43 & Syzygium cumini (L) Skeels & 02 & 02 & 20 & 01 & 0.2 & 0.98 & 0.90 & 1.45 & 4.33 & 6.68 \\
\hline 44 & $\begin{array}{l}\text { Syzygium tamilnadensis } \\
\text { Radhakr.\& Chithra }\end{array}$ & 01 & 01 & 10 & 01 & 0.1 & 0.07 & 0.45 & 0.72 & 0.30 & 1.47 \\
\hline 45 & Tectona grandis L. & 01 & 01 & 10 & 01 & 0.1 & 0.08 & 0.45 & 0.72 & 0.35 & 1.52 \\
\hline 46 & Terminalia bellerica Roxb. & 03 & 03 & 30 & 01 & 0.3 & 2.37 & 1.35 & 2.18 & $\begin{array}{c}10.4 \\
8\end{array}$ & $\begin{array}{c}14.0 \\
1\end{array}$ \\
\hline 47 & Terminalia chebula Retz. & 01 & 01 & 10 & 01 & 0.1 & 1.58 & 0.45 & 0.72 & 6.99 & $\begin{array}{c}14.0 \\
1\end{array}$ \\
\hline 48 & Terminalia elliptica Willd. & 01 & 01 & 10 & 01 & 0.1 & 0.13 & 0.45 & 0.72 & 0.57 & 1.74 \\
\hline 49 & Thespesia populnea (L.) Soland. & 01 & 01 & 10 & 01 & 0.1 & 0.38 & 0.45 & 0.72 & 1.68 & 2.85 \\
\hline 50 & $\begin{array}{l}\text { Ventilago maderaspatana } \\
\text { Gaertn.Var. maderaspatana }\end{array}$ & 01 & 01 & 10 & 01 & 0.1 & 0.01 & 0.45 & 0.72 & 0.04 & 1.21 \\
\hline 51 & Vitex leucoxylon $L$ & 02 & 01 & 10 & 02 & 0.2 & 0.22 & 0.90 & 0.72 & 0.97 & 2.59 \\
\hline 52 & Xantolis tomentosa (Roxb.) Raf. & 08 & 05 & 50 & 1.6 & 0.8 & 0.07 & 3.61 & 3.64 & 0.30 & 7.52 \\
\hline 53 & Zanthoxylum rhetsa Dc. & 06 & 05 & 50 & 1.2 & 0.6 & 0.28 & 2.71 & 3.64 & 1.23 & 7.58 \\
\hline 54 & $\begin{array}{l}\text { Ziziphus rugosa Lam. } \\
\text { Var. rugosa }\end{array}$ & 02 & 02 & 20 & 01 & 0.2 & 0.03 & 0.90 & 1.45 & 0.13 & 2.48 \\
\hline
\end{tabular}

(IT = Total no. of individuals; OCC = Occurrences; FRE = Frequency; $\mathrm{ABD}=$ Abundance; $\mathrm{DEN}=$ Density; BA =

Basal area in Sq. m., RF = Relative frequency; R. Do. = Relative dominance; R. De. = Relative density; I.V.I. = Importance value index)

Table No. 2: Frequency classes and No. of plant species observed:

Frequency \% Frequency class No. of species Observed

\begin{tabular}{ccc}
\hline $0-20$ & A & 33 \\
\hline $21-40$ & $\mathrm{~B}$ & 14 \\
\hline $41-60$ & $\mathrm{C}$ & 04 \\
\hline $61-80$ & $\mathrm{D}$ & 01 \\
\hline $81-100$ & $\mathrm{E}$ & 02 \\
\hline Total species & & 54
\end{tabular}


The analysis of frequency classes of reported species from study area falls in five classes. ' $A$ ' class is represented by 33 species followed by ' $B$ ' class with having 02 species and ' $D$ ' class with having 01 species, so this result shows heterogeneity in the vegetation of Wanzaloli sacred grove

\section{Acknowledgement:}

Author is thankful to University of Mumbai for financial support for the completion of the Minor research project.

\section{References:}

Anonymous 1962. Maharashtra state Gazetteers: Ratnagiri District. Directorate of Printing and stationery, Maharashtra state, Bombay.

Anonymous, 2008-2012. Progress Report of Agro metrological Scheme, Department of Agronomy, Dr. B. S. Konkan Krishi Vidyapeeth, Dapoli, Dist. Ratnagiri (M.S.).

Cook, T., 1901-1908. The flora of the Presidency of Bombay. (Reprint 1958) Botanical survey of India, Howrah, I-III.

Jain, S. K. and Rao, R. R., 1977.A Handbook of Field and Herbarium Methods. Today and Tomorrow's Printers and Publishers, New Delhi: 22-72.

Kulkarni, B. G., 1988. Flora of Sindhudurg District.Botanical Survey of India, Culcutta.

Kulkarni, D. K. and Nipunage, D. S., 2009.

Floristic diversity and ecological evaluation of
'Dhup-Rahat' sacred grove form Pune district. GEOBIOS, 36 : 298-302.

Mishra, R. 1968. Ecology Work book .Oxford and IBH, Calcutta, India.

Pandeya, S.C., Puri, G.S. and Signh, J. S. 1968. 'Research Methods in Plant Ecology', Asia Publishing House, Bombay.

Sharma, B. D., Karthikeyan, S. and Singh, N. P., 1996. Flora of Maharashrta state Monocotyledons. BSI. Calcutta.

Singh, N.P. and Karthikeyan, S. 2000. Flora of Maharashrta state. Dicotyledones, Vol.I BSI, Calcutta.

Singh, P., Lakshinarasimshan, P., Karthikeyan, S. and Prasanna., 2001. Flora of Maharashtra state Dicotyledones, Vol. II BSI, Calcutta.

Unnikrishnan, E., 1990. "Part played by sacred groves in Local Environments," Centre for Science and Environment, New Delhi.

Vartak, V. D. and Gadgil, M., 1981. Relic Forest pockets of Panshet water catchment area, Poona District, Maharashtra statc.,Biovigyanam 7: 145148.

Vartak, v. D., Kumbhojkar, M. S. and Dabadghao, V., 1986.sacred groves - A sanctuary for lofty trees and Lianas. Proc. Seminar on Eco-development of Western Ghats: 55: 59 .

Vartak, V. D., Kumbhojkar, M. S. and Nipunage, 1987. Sacred groves of Tribal areas along the Western ghats: Treasure trove of medicinal plants. Bulletin of Medico Ethno Botanical Research, 8 (1-2): 77 - 88.

\section{Well conserved sacred grove of Wanzaloli}

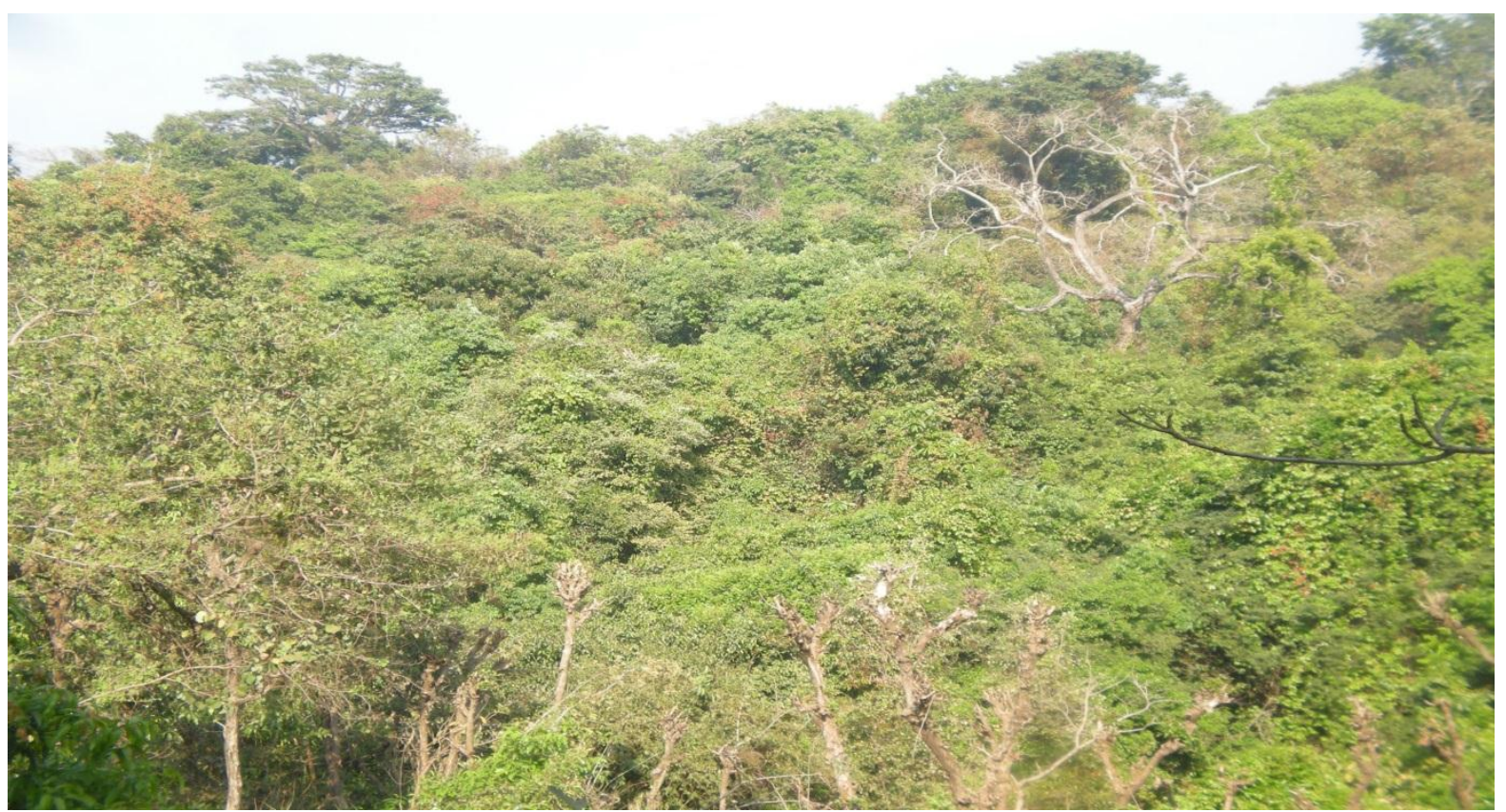

